\title{
A Case of Metastatic Rectal Carcinoma to the Frontal Sinus
}

\author{
Seok Kim, Tae Young Jung, Bo Young Kim, and Tae Jung Park \\ Department of Otolaryngology, Maryknoll Medical Center, Busan, Korea
}

\section{전두동에 전이된 직장암 1 예}

김 석 · 정태영 · 김보영 · 박태정

메리놀병원 이비인후과

\author{
Received February 12, 2016 \\ Revised April 21, 2016 \\ Accepted April 30, 2016 \\ Address for correspondence \\ Tae Jung Park, MD \\ Department of Otolaryngology, \\ Maryknoll Medical Center, \\ 121 Junggu-ro, Jung-gu, \\ Busan 48972, Korea \\ Tel $+82-51-461-2692$ \\ Fax +82-51-462-9419 \\ E-mail p791216@naver.com
}

\section{서 론}

직장암은 결장암과 합쳐 대장암으로 한국에서 3 번째로 흔 한 암이며,1) 간, 폐, 골, 뇌 등 다양한 원격 전이를 일으키지만,2) 부비동으로 전이는 매우 드물다. ${ }^{3)}$ 전두동으로 전이된 직장암 은 아직 국내에서 보고된 예가 없고, 서구에서도 문헌을 찾아 보기 힘들다. 저자들은 직장암이 전두동으로 전이되었던 1예 를 경험하였기에 이를 문헌고찰과 함께 보고하는 바이다.

\section{증 례}

66세 여자 환자가 2개월 전부터 발생한 두통과 전두부의 종창을 주소로 내원하였다. 과거력상 환자는 3년 전 직장선암 (rectal adenocarcinoma, T3N2bM0, Stage III)을 진단받고 본원 외과에서 저위전방절제술을 시행받았으며 이후 12 회의

This is an Open Access article distributed under the terms of the Creative Commons Attribution Non-Commercial License (http://creativecommons.org/licenses/by-nc/4.0) which permits unrestricted non-commercial use, distribution, and reproduction in any medium, provided the original work is properly cited.
항암화학요법(FOLFOX-4, oxaliplatin-based regimens) 후 내원 2년 전 폐의 다발성 전이가 발견되었으나 이후 추적관찰 중 유의한 변화는 없는 상태였다. 이학적 검사상 우측 전두 부의 종창과 우측 안구주위 부종 외 우안의 안검하수가 관찰 되었으며(Fig. 1), 비내시경 소견상 특이 소견은 없었고 경부 림프절 종대는 촉지되지 않았다.

비부비동 전산화단층촬영 및 자기공명영상에서 우측 전두 부와 전두동 내에 불균일하게 조영증강이 되는 종물이 관찰 되었고(Fig. 2), 인접하고 있는 두개저와 뇌수막을 침범하며 상시상 정맥동(superior sagittal sinus)에서 두정엽까지 뇌수 막은 물론 두개골 그리고 두피까지 침습한 양상(Fig. 3)을 보 여 전이성 부비동 종양 가능성을 염두에 두고 전신마취 하에 내시경적 종양제거술을 시행하였다.

수술 소견상 종괴는 $2.9 \times 1.4 \times 1.5 \mathrm{~cm}$ 의 크기로 불규칙한 표면을 보였으며 우측 전두동의 후면에 붙어 주변 점막과 유 착 소견을 보였다. 술 중 시행한 동결절편조직검사에서 악성 종양으로 확인되었으나 정확한 진단은 불가능하여 종물 축 소술과 전두동 절개술을 시행 후 수술을 종료하였다. 수술 

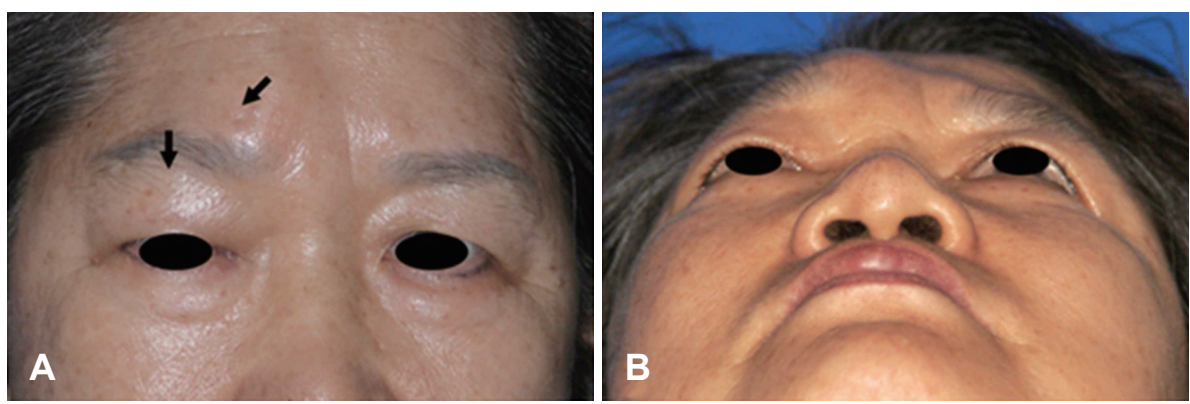

Fig. 1. Preoperative photographs on frontal view $(A)$ and submental view (B) show periorbital and forehead swelling (arrows).
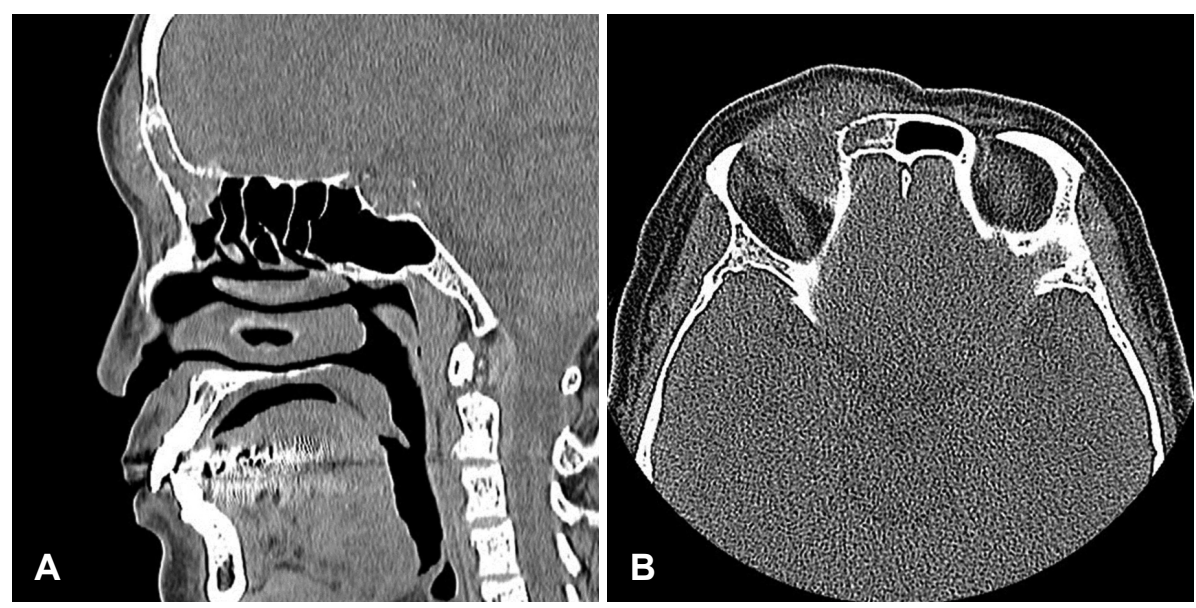

Fig. 2. Preoperative non-enhanced $\mathrm{CT}$ images of frontal sinus tumor. Sagittal view shows soft tissue density in frontal sinus and soft tissue swelling on anterior scalp (A). Axial view demonstrates mass lesion originated from the right frontal sinus invaded the superior orbital wall and orbital cavity (B).
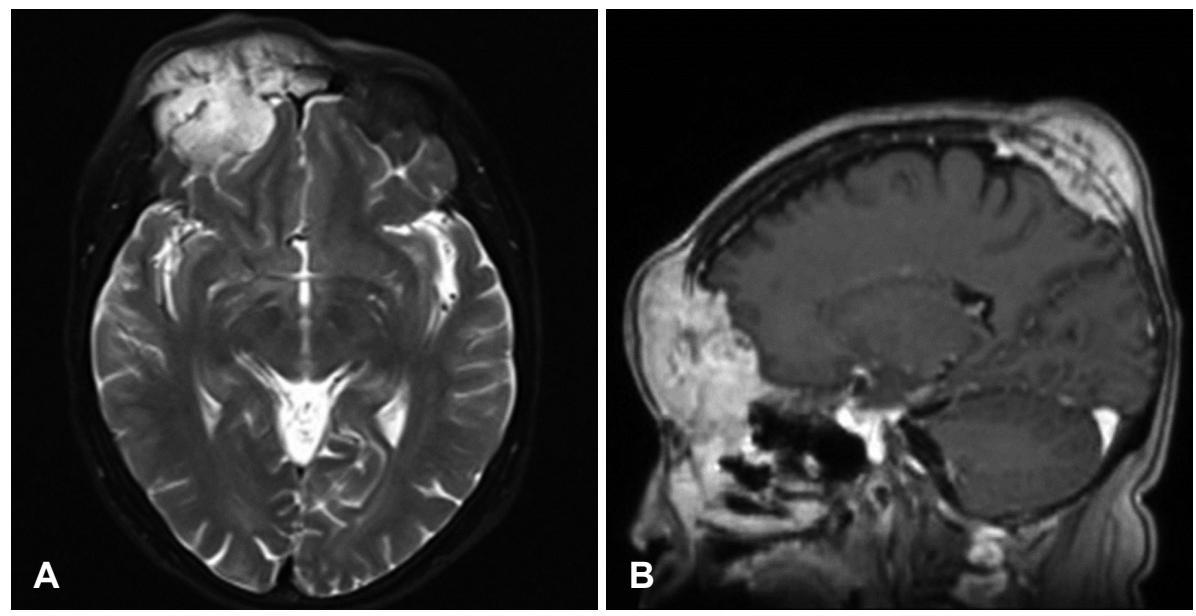

Fig. 3. Preoperative MRI images of frontal sinus tumor. Axial T2-weighted MRI show inhomogeneous mass originated from the right frontal sinus with invasion to the orbit and anterior scalp (A). Sagittal T2-weighted MRI show mass lesion invades anterior skull base and cerebral meninges, skull and scalp around parietal area (B).

후 경부 림프절 및 기타 장기로의 추가 전이 여부 확인을 위하 여 시행한 양전자방출단층촬영상 기존의 폐전이와 우측 전 두부와 전두동 외 다른 장기에서의 원격전이 소견은 관찰되 지 않았다.

병리조직검사에서 결체조직으로 침윤하며 복잡한 선구조 를 가진 중등도로 분화된 유두상 선암종이 관찰되었으며 이는 환자의 기존 직장암 조직 소견과 일치하였고, 면역조직화학 염색에서 cytokeratin 7에 음성, cytokeratin 20에 양성 소견을 보여 전이성 선암종으로 판명되었다(Fig. 4).

최종 조직검사 결과에 따라 두개안면절제술 및 예방적 경부
절제술을 계획하여 권유하였으나 환자는 수술적 치료를 거부 하여 상급병원으로 전원, 임상시험 프로그램에 참여하게 하는 등 보조 항암화학요법을 시행했지만 치료에 별다른 반응을 보이지 않았다. 현재 정기적으로 외래에서 경과 관찰 중이다.

\section{고 찰}

직장암은 대장에서 결장암에 이어 2 번째로 흔한 암으로 이 들을 합친 대장암은 미국에서 암으로 인한 사망 중 3 번째로 흔하다. ${ }^{4}$ 한국에서도 국립암센터 자료에 따르면 대장암은 3번 

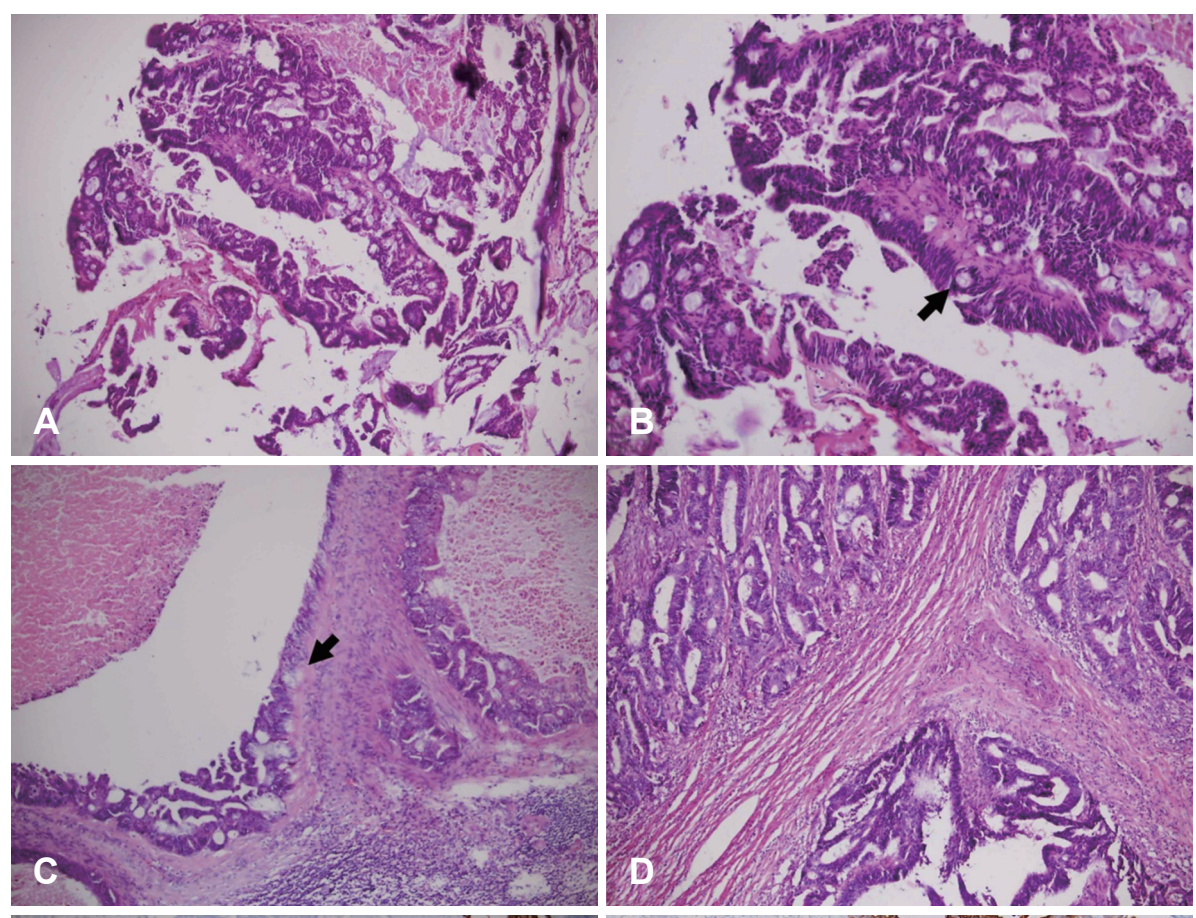

Fig. 4. Hematoxyling \& eosin stain. Histopathologic section of tissues from frontal sinus shows moderately differentiated adenocarcinoma with mucin secretion (arrow) in stroma $(\times 100)(A),(\times 200)(B)$. The colorectal adenocarcinoma characterized by proliferation of atypical glandular structures (arrow) and necrotic debris within the lumen $(\times 100)(C$ and D). Immunohistochemical staining. Cytokeratin 7 is immunopositive with normal epithelium but immunonegative with neoplastic glands $(\times 100)$ (E). Cytokeratin 20 expression is detected in adenocarcinoma glands E

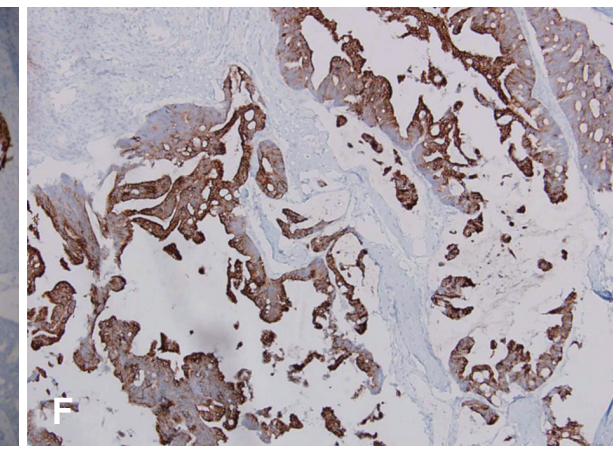
$(\times 100)(F)$.

째로 흔한 암이며, ${ }^{1)}$ 서구화된 식습관 등의 환경적인 원인으 로 그 발생 빈도는 꾸준히 증가할 것으로 보인다. ${ }^{5)}$

비부비동으로의 원격전이는 매우 드물어 1951년부터 2011 년까지 167 건이 증례로 보고되어 있으며 가장 흔한 원발암은 신세포암이며 상악동을 가장 많이 침범하는 것으로 알려져 있다. ${ }^{6}$ 전 세계적으로 위장관암의 비부비동 원격전이는 모두 8건, 그 중 직장암에서의 전이는 3건이 보고되었으며, ${ }^{3,7,8)}$ 한국 에서는 아직 보고된 바가 없다.

비부비동에 발생한 전이암의 증상은 비특이적으로, 비출 혈, 비폐색, 안면통증 등의 비증상이나, 안검하수, 복시, 시력저 하 등의 안구증상을 나타낼 수 있고, ${ }^{6,9,10)}$ 본 증례에서는 부종 과 안검하수를 보였다.

본 증례에서 전두동 선암종의 전이성 병소 여부를 평가하기 위하여 직장암과의 조직학적인 일치성 외 면역조직화학 염색 을 활용하였다. Cytokeratin 7과 cytokeratin 20에서 모두 양 성인 경우 비부비동에서 기원한 장형 선암종일 가능성이 크고 cytokeratin 7에서 음성, cytokeratin 20에서 양성일 경우 장 에서 기원한 전이성 선암종일 가능성이 큰데, ${ }^{3,11}$ 저자들의 증 례에서도 cytokeratin 20에서만 양성을 보여 전두동에 전이 된 직장암으로 진단할 수 있었다.

$T_{\text {Tanaka }}{ }^{8)}$ 는 사골동에 전이된 직장암을 기술하며 추골정맥 총을 통한 전이 경로를 설명하였고, 그 외 두경부로 전이된 암 에 관한 다수의 증례 보고들 역시 추골정맥총을 주요 전이 경 로로 제시하였으나, ${ }^{6,12,13)}$ 본 증례에서 발생한 직장암의 원격 전이는 폐 전이 이후에 전두동과 두개골 등에 전이된 것으로 혈행성 또는 경사상판(transcribrosal) 외 다른 전이 경로가 있 을 것으로 추정된다. ${ }^{6,12,14)}$

이처럼 원발성 직장암으로부터 비부비동으로의 전이는 매 우 희귀하며 어떠한 원인과 경로로 전이가 발생하는지는 잘 알려져 있지 않다. 또한 비부비동으로 암종이 전이되었을 경 우, 진단 시점에 병기가 높아 방사선 치료 및 항암 화학요법과 같은 고식적 치료 방법에 의존하게 되며 예후가 좋지 않으므 
로 이에 대한 연구가 더욱 필요할 것으로 사료된다.

\section{REFERENCES}

1) Jung KJ, Won D, Jeon C, Kim S, Kim TI, Jee SH, et al. A colorectal cancer prediction model using traditional and genetic risk scores in Koreans. BMC Genet 2015;16:49.

2) Qiu M, Hu J, Yang D, Cosgrove DP, Xu R. Pattern of distant metastases in colorectal cancer: a SEER based study. Oncotarget 2015;6(36): 38658-66.

3) Conill C, Vargas M, Valduvieco I, Fernández PL, Cardesa A, Capurro S. Metastasis to the nasal cavity from primary rectal adenocarcinoma. Clin Transl Oncol 2009;11(2):117-9.

4) Siegel R, Desantis C, Jemal A. Colorectal cancer statistics, 2014. CA Cancer J Clin 2014;64(2):104-17.

5) Shin A, Kim KZ, Jung KW, Park S, Won YJ, Kim J, et al. Increasing trend of colorectal cancer incidence in Korea, 1999-2009. Cancer Res Treat 2012;44(4):219-26.

6) Abi-Fadel F, Smith PR, Ayaz A, Sundaram K. Paranasal sinus involvement in metastatic carcinoma. J Neurol Surg Rep 2012;73(1): 57-9.

7) Bień S, Kamiński B, Okła S, Kopczyński J. [Metastasis of rectal adenocarcinoma to the skull base and paranasal sinuses, with unusual clinical symptoms]. Otolaryngol Pol 2005;59(4):627-30.

8) Tanaka K. A case of metastases to the paranasal sinus from rectal mucinous adenocarcinoma. Int J Clin Oncol 2006;11(1):64-5.

9) Nelson EG, Goldman ME, Hemmati M. Metastatic carcinoma of the ethmoid sinus. Otolaryngol Head Neck Surg 1990;103(1):120-3.

10) Clarkson JH, Kirkland PM, Mady S. Bronchogenic metastasis involving the frontal sinus and masquerading as a Pott's puffy tumour: a diagnostic pitfall. Br J Oral Maxillofac Surg 2002;40(5):440-1.

11) Resto VA, Krane JF, Faquin WC, Lin DT. Immunohistochemical distinction of intestinal-type sinonasal adenocarcinoma from metastatic adenocarcinoma of intestinal origin. Ann Otol Rhinol Laryngol 2006;115(1):59-64.

12) Fyrmpas G, Adeniyi A, Baer S. Occult renal cell carcinoma manifesting with epistaxis in a woman: a case report. J Med Case Rep 2011;5: 79.

13) Nanbu A, Tsukamoto T, Kumamoto $Y$, Aoki M, Hirose T, Asakura $\mathrm{K}$, et al. Squamous cell carcinoma of bladder diverticulum with initial symptoms produced by metastasis to maxillary sinus. Eur Urol 1988;15(3-4):285-6.

14) Monserez D, Vlaminck S, Kuhweide R, Casselman J. Symmetrical ethmoidal metastases from ductal carcinoma of the breast, suggesting transcribrosal spread. Acta Otorhinolaryngol Belg 2001;55(3):251-7. 